\title{
Territorial and Branch Assessment of Water Management Balance of Georgia Based on Differential Estimation and Modeling of Economic Impact on Water Resources
}

\author{
Nino Kezevadze \\ Directorate, ltd “Georgian Water and Power", Tbilisi, Georgia
}

Email address:

nkezevadze@georgianwater.com

To cite this article:

Nino Kezevadze. Territorial and Branch Assessment of Water Management Balance of Georgia Based on Differential Estimation and Modeling of Economic Impact on Water Resources. American Journal of Environmental Protection. Special Issue: Applied Ecology: Problems, Innovations. Vol. 4, No. 3-1, 2015, pp. 51-57. doi: 10.11648/j.ajep.s.2015040301.19

\begin{abstract}
Political and social-economic coups in the 1990s of the last century in Georgia, as well as in countries of the former USSR and East Europe has left its mark on the water management problems of those countries. Thus, for alternative assessment of probable water economy balance first priority is to select a representative period in dynamics for utilization of water resources. For Georgia such period is 1980s of the last century, as the most active period in historic economic development. The indicated period is characterized by comparatively reliable water management statistics, with stable socioeconomic background and maximum anthropogenic load on water resources. For the very period branch and territorial structure of water management balance have been studied. Based on that alternative forecast have been assessed for the first quarter of the current century,according to the planned scenario during the above mentioned period. The indicated studies have been carried out based on differential assessment and mathematical modeling of economic load on water resources. Water management models have been developed for certain categories of water consumers using economic, demographic and ecological criteria.
\end{abstract}

Keywords: Water Resources, Water Management Balance, Mathematical Modeling

\section{Introduction}

Political cataclysms occurring in the country in the 1990s of the last century predetermined recessionary drastic changes in the social and economic sphere. Correspondingly,a new reality has had influence on water economy topics. The unpredicted development scenario of demographic and business processes hasmade topical to study spatial and time dynamics of water management based not only on statistical data, but also on mathematic modeling using generalized parameters and criteria which are determined by indirect method.

Assessment of spatial and time dynamics requires conformity of quality of territorial differentiation with the accuracy of determination of water utilities, components and level of detail on the one hand, and time aspect, i.e. adequate selection of the study period, on the other hand.

Branch and territorial assessment of water economy balance of Georgia may be carried out taking into account only landscape and business activity of the area, which determines the locality of territorial distribution of the elements of water and water economy balance. From this point of view, the first and the most important stage of territorial differentiation is to divide the territory of Georgia into two natural and economic regions - West and East regions. The present article deals with branch and territorial topics of water management balance.

Taking into consideration the above complexities for assessment of spatial and time dynamics of water economy balance, especially problematic is to select a representative period, which at more adequately reflects the possibilities of economic development of the country from the point of view of hydro recourse potential. Such representative period for this article is the 1980s of the last century as the most active period in the economic development of the country with comparatively reliable water economy statistics, stable social and economic background and maximum anthropogenic impact on water resources. 


\section{Overview of Water Resources and Water Management Balances of Georgia}

Water budget analysis (hydrologic inventory) is carried out based on comparison of certain economic branches, i.e. water used by main water consumers with the existing resource potential. On this basis first stage of the water balance calculation is to establish the resource potential of the area.

The resource potential of rivers in Georgia comprises transit and local flows. Local river flows, established and adjusted on the basis of water resource balance assessment, excluding transit flows of River Mtkvari, Chorokhi and North Slope of the Caucasus makes up 57, $9 \mathrm{~km} 3$, and steady flow $-19,6 \mathrm{~km} 3$ (Steady flow's components are underground flows, flows regulated by water reservoirs and total useful groundwater storage). In addition to West Georgia appropriate indicators are 43, 3 and 12, $3 \mathrm{~km} 3$, and for East Georgia - 14, 6 and 7, 2 km3.

According to world standards and taking into account demographic data, Georgia belongs to average river resource serviced area. This indicator (Specific water provision) for complete flow equals to 11 thousand $\mathrm{m} 3 /$ year and for underground flow $-3,5$ thousand $\mathrm{m} 3$ /year per capita. While the world average indicator is 11 and 4 thousand m3/year correspondingly. Naturally unequal geographical distribution of water resources of Georgia between west and east regions is reflected on the surface as well as an underground specific water provision. Surface and underground specific water provision in West Georgia equals to 19 and 5 thousand $\mathrm{m} 3$ correspondingly, and for East Georgia - 5 and 2 thousand $\mathrm{m} 3 /$ year per capita. In addition, this inequality is deepened by the unequal location of the population according to height. In particular, $88 \%$ of the population of Georgia is concentrated in the lowland. For this reason lowland of East Georgia is less serviced by river resources - 0,45 thousand $\mathrm{m} 3$ /year, and mountain regions of West Georgia are characterized by high water provision -317 thousand $\mathrm{m} 3$ /year per capita.

The unequal distribution of the population, according to altitude, in its turn, has functional relations with location of economic branches which indicates to the fact that share ofindustrial production produced in the lowland of Georgia in comparison with average geographical indicator in the $80 \mathrm{is}$ of the last century was $90 \%$. This fact naturally specifies deepening inequality of anthropogenic impact and correspondingly widening of the water resource deficit in the lowland area of Georgia.

Over a century hydrology and its allied sciences pay attention to issues of anthropogenic effects on water resources. Initially changes of water regime as a result of different economic activities have been studied. Later scientific and technological revolution has made the issue of qualitative transformation of natural waters topical. Lately hydrologic range of problems has become a priority. It is related to modern climatic and possible anthropogenic changes. Scientists of State Institute of Hydrology, Water
Problem Institute and Geography Institute under Academy of Sciences of former USSR and its republics. Methods for calculation of hydrological changes and transformations have been developed, alternative predictive assessments of possible states of water resources have been carried out all over the world for certain regions and countries [1,2].

Indicated methods and predictive assessments for Georgia, as a mountainous country, or an area with high-altitude, length regularities length have been carried out based on basic research of altitudinal regularities of water resources and water balance elements, which has been studied for decades at the Vakhushti Bagrationi Institute of Geography of Academy of Sciences of Georgia [3]. As for water management balance and its predictive assessments, they are subject to the principle of altitudinal regularities and they require interpretation according to altitudinal belts and natural zones.

It should be noted that for the entire world, as well as for majority of Non-CIS States, predictive assessments of water management balance have been justified. As for post-socialist space, including Georgia, the transformation of water resources and water balance from the beginning of the 1990s have been developing under unpredictable scenario. Obviously it is the result of those political, social and economic changes which involved former Soviet Union and Eastern Union countries. Against the background of the world economic growth, economic downfall emerged in those countries in the 1990s, which in its turn, had an impact on the quantity and quality of water resources. Over the period of modern social and economic crisis, at the expense of sharp decline in industrial and domestic water consumption, total water consumption, volume of recycled and reused water, as well as volumes of waste waters and non-recoverable loss, have decreased. To a certain extent, it has improved quantitative and qualitative state of water resources. This tendency has been kept to this day. Though it is evident that it is temporal because of economic depression and under depression the state will not be able to preserve economic stability for a long period. Prerequisite for overcoming economic and social crisis in the country is industrial expansion, development of agriculture, tourism and communal services. Certainly those processes will thoroughly change components of water economy balance for the worse. This is the reason why, in the process of economic use of water resources against the background of topical economic load,it is necessary to substantively change management principles, activate protective measures in terms of quantity and quality.

It should also be noted that the economic crisis in Georgia has been followed by bringing to a stop certain metering and control systems. Under shortage of statistical data for the given period, it is possible to establish expenses on water economy balance elements, first of all, on water intake, used water and sewerage, based on theoretical and empirical methods. Though using similar methods for observation and metering period is frequently inevitable, as metering of water economy elements has always been characterized by poor accuracy. 


\section{Mathematical Model of Water Management Balance}

For the purpose of differential assessment and mathematical modeling of economic load on water resources the author of this article has developed and submitted empirical formula and algorithms, based on which water management balance should be calculated in the case of statistical data unreliability as well as during predictive research.

Main formulae of water management balance may be represented in the following way:

$$
\sum_{\mathrm{i}=1}^{\mathrm{n}} \mathrm{Q}_{\mathrm{i}, \mathrm{b}}=\sum_{\mathrm{i}=1}^{\mathrm{n}}\left(\mathrm{Q}_{\mathrm{i}, \mathrm{n}}-\mathrm{Q}_{\mathrm{i}, \mathrm{o}}+\mathrm{Q}_{\mathrm{i}, \mathrm{m}}\right)
$$

where $Q_{i, b}$ is the volume of water taken at a certain time by $i-$ consumer (industry, population, agriculture, etc.), $\mathrm{Q}_{\mathrm{i}, \mathrm{n}}-$ volume of used water, $\mathrm{Q}_{\mathrm{i}, \mathrm{o}}$-recycled water consumption and $\mathrm{Q}_{\mathrm{i}, \mathrm{m}}$-volume of water lost on transportation.

Volume of used water:

$$
\sum_{\mathrm{i}=1}^{\mathrm{n}} \mathrm{Q}_{\mathrm{i}, \mathrm{n}}=\sum_{\mathrm{i}=1}^{\mathrm{n}}\left(\mathrm{Q}_{\mathrm{i}, \mathrm{g}}-\mathrm{Q}_{\mathrm{i}, \mathrm{c}}+\mathrm{Q}_{\mathrm{i}, \mathrm{e}}+\mathrm{Q}_{\mathrm{i}, \mathrm{o}}\right)
$$

where $Q_{i, g}$ is taken back loss, $Q_{i, c}-$ volume of waste water and $\mathrm{Q}_{\mathrm{i}, \mathrm{e}}$-volume of water returned to the riverbed.

With an account of (2) final definition will be as follows:

$$
\sum_{\mathrm{i}=1}^{\mathrm{n}} \mathrm{Q}_{\mathrm{i}, \mathrm{b}}=\sum_{\mathrm{i}=1}^{\mathrm{n}}\left(\mathrm{Q}_{\mathrm{i}, \mathrm{g}}-\mathrm{Q}_{\mathrm{i}, \mathrm{c}}+\mathrm{Q}_{\mathrm{i}, \mathrm{e}}+\mathrm{Q}_{\mathrm{i}, \mathrm{m}}\right)
$$

As it was mentioned above, drawing up water management balance requires availability of large data base about resources and functions of the basin, quantitative, as well as qualitative, which, in most cases, leading bodies of water utility system are not able to provide. Under the conditions of deficit of materials and unreliable assessment of the current water economy balance processes may be carried out only by rough estimate based on economic, water and ecological standards. Main algorithms for calculating water economy elements may be represented in thefollowing way:

Water consumption volume in domestic sector in the course of time $(\mathrm{t})$

$$
\mathrm{Q}_{1}(\mathrm{t})=\mathrm{K}_{1}\left[\sum_{\mathrm{j}^{\prime}=1}^{\mathrm{R}} \mathrm{q}_{\mathrm{j}^{\prime}}(\mathrm{t}) \mathrm{Z}_{\mathrm{j}^{\prime}}(\mathrm{t}) \sum_{\mathrm{j}^{\prime \prime}=1}^{\mathrm{R}} \mathrm{q}_{\mathrm{j}^{\prime \prime}}(\mathrm{t}) \mathrm{Z}_{\mathrm{j}^{\prime \prime}}(\mathrm{t})\right]
$$

where $q_{j^{\prime}}$ and $q_{j^{\prime \prime}}$ - are water use rates for city and village population (1/day per capita), and $\mathrm{j}^{\prime}$ and $\mathrm{j}^{\prime \prime}$ - settlement category, $Z_{j^{\prime}}$ and $Z_{j^{\prime \prime}}$ - corresponding number of the population of the settlement categories, and $\mathrm{K}_{1}$-coefficient for regulating measurements.

In industrial - business sector

$$
\mathrm{Q}_{2}(\mathrm{t})=\mathrm{K}_{2} \sum_{\mathrm{j}^{\prime \prime \prime}=1}^{\mathrm{R}} \mathrm{q}_{\mathrm{j}^{\prime \prime \prime}}(\mathrm{t}) \mathrm{V}_{\mathrm{j}^{\prime \prime \prime}}(\mathrm{t})
$$

where $\mathrm{q}_{\mathrm{j}^{\prime \prime \prime}}$ is water consumption per production unit (specific water-retaining of the product), and $V_{j^{\prime \prime \prime}}$-volume of the corresponding industrial production.

In agriculture, particularly in livestock sector

$$
\mathrm{Q}_{3}(\mathrm{t})=\mathrm{K}_{1}\left[\sum_{\mathrm{j}^{\prime \prime \prime \prime}=1}^{\mathrm{R}} \mathrm{q}_{\mathrm{j}^{\prime \prime \prime \prime}}(\mathrm{t}) \mathrm{Z}_{\mathrm{j}^{\prime \prime \prime \prime}}(\mathrm{t})\right]
$$

where $\mathrm{Z}_{\mathrm{j}^{\prime \prime \prime \prime}}$ and $\mathrm{q}_{\mathrm{j}^{\prime \prime \prime \prime}}$-correspondingly numbered of $\mathrm{j}^{\prime \prime \prime \prime}$ type and water consumption norm.

Volume of water necessary for $\mathrm{j}$ type culture in irrigation farming during vegetation period $\left(\mathbf{t}^{\prime}\right)$ may be expressed in an algorithm:

$$
\begin{array}{r}
\mathrm{Q}_{4}(\mathrm{t})= \\
\sum_{\mathrm{j}=1}^{\mathrm{R}}\left\{\begin{array}{r}
\sum_{\mathrm{j}=1}^{\mathrm{R}} \mathrm{N}_{\mathrm{j}}(\mathrm{t}) \mathrm{F}_{\mathrm{j}}(\mathrm{t}) * * \\
\mathrm{E}\left(\mathrm{t}^{\prime}\right)-\mathrm{W}\left(\mathrm{t}^{\prime}\right), \text { when } \mathrm{W}\left(\mathrm{t}^{\prime}\right)<\mathrm{E}_{0}\left(\mathrm{t}^{\prime}\right)
\end{array}\right\}\left(\mathrm{t}^{\prime}\right) \mathrm{F}_{\mathrm{j}}(\mathrm{t}) \quad \text { (7) }
\end{array}
$$

where $\mathrm{N}_{\mathrm{j}}$ is irrigation rate, $\mathrm{F}_{\mathrm{j}}$-culture acreage, $\mathrm{E}_{0}$-evaporation during vegetation period, and $\mathrm{W}$ - total moisture of the area (infiltration)for the same period. It characteristics for rehydration resources which constitute evaporation and ground water inflow.

Consumptive water use during a certain $(\mathbf{t})$ period will be:

$$
\mathrm{Q}(\mathrm{t})=\sum_{\mathrm{i}=1}^{\mathrm{n}} \mathrm{Q}_{\mathrm{i}}(\mathrm{t})=\sum_{\mathrm{i}=1}^{\mathrm{n}} \sum_{\mathrm{j}=1}^{\mathrm{R}} \mathrm{K}_{\mathrm{i}} \mathrm{q}_{\mathrm{ij}}(\mathrm{t}) \mathrm{Y}_{\mathrm{ij}}(\mathrm{t})
$$

where $\mathrm{q}_{\mathrm{ij}}$ is specific flow intensity per unit index, $\mathrm{Y}_{\mathrm{ij}}$ is the volume of the corresponding index.

A comparison of total volume of water consumption calculated by proposed an empirical formula and algorithms to the existing resources is an availability index (water resources) of the area.

As for quality state of water in natural objects, it is defined by pollution and self-purification of the reservoir (basin). Pollution depends on point and diffuse sources, and selfpurification of the reservoir (basin), on the intake object, the number of its resources and primary quality. For assessment of self-purification, first of all necessary volume of water for watering, we propose the following image:

$$
\mathrm{Q}_{\mathrm{p}}=\max _{\mathrm{j}(\epsilon 1 ; R), \mathrm{p}}=\max \left\{\sum_{\mathrm{i}=1}^{\mathrm{n}}\left[\frac{\mathrm{P}_{\mathrm{ij}, \mathrm{c}} / \mathrm{Q}_{\mathrm{i}, \mathrm{c}}+\mathrm{K}_{\mathrm{j}, \mathrm{a}}}{\mathrm{K} \prime_{\mathrm{j}} \mathrm{Q}_{\mathrm{i}, \mathrm{c}}}\right]\right\}, \text { byj } \epsilon 1 ; R
$$

where $\mathrm{P}_{\mathrm{ij}, \mathrm{c}}$ is i-total concentration of waste waters discharged in the water object against $\mathrm{j}$ component, $\mathrm{K}_{\mathrm{j}, \mathrm{a}}$-primary concentration of the intake object against $\mathrm{j}$ component, $\mathrm{K}_{\mathrm{j}}{ }_{\mathrm{j}}$ is the maximum permissible concentration of $\mathrm{j}$ component.

In figure (9) reciprocal dilution for water consumption $i$ sector $\Delta \mathrm{ij}$ is expressed by the following formulae:

$$
\Delta \mathrm{ij}=\max _{\mathrm{j}(\epsilon 1 ; \mathrm{R})}\left[\left(\mathrm{K}_{\mathrm{ij}, \mathrm{c}}+\mathrm{K}_{\mathrm{j}, \mathrm{a}}\right) / \mathrm{K}_{\mathrm{j}}^{\prime}\right]
$$

If the intake object is capable to satisfy the conditions:

$$
\mathrm{Q}_{\mathrm{a}} \geq \mathrm{Q}_{\mathrm{s}}+\mathrm{Q}_{\mathrm{p}}=\mathrm{Q}_{\mathrm{s}}+\left[\max \sum_{\mathrm{i}=1}^{\mathrm{R}} \Delta \mathrm{ij}(\epsilon 1 ; n)\right] \mathrm{Q}_{\mathrm{i}, \mathrm{c}}
$$

It may be considered that saturation quality corresponds to self-purification of the basin and thus qualitative load is allowed for the specific water object.

In equation (11) $Q_{a}$ is water flow in the intake object, $Q_{s}-$ sanitary flow of the water object, i.e. minimum flow, which meets sanitary standards of the river bed.

It should also be noted that water quality criteria are fixed indexes only in the concrete situation. As usual, they must have the determinate flexibility (from the point of view of one sign deviation - to reduction). In particular, if for short- 
term task maximum permissible concentration is acceptable $\mathrm{K}_{\mathrm{j}}^{\prime}$, for long-term tasks the following condition must become deeper:

$$
\mathrm{K}_{\mathrm{j}}^{\prime \prime}<\mathrm{K}_{\mathrm{j}}^{\prime} \text {, i. e., } \quad \sum_{\mathrm{j}=1}^{\mathrm{R}} \mathrm{K}_{\mathrm{j}}^{\prime \prime} / \mathrm{K}_{\mathrm{j}}^{\prime} \leq \mathrm{R}
$$

where $\mathrm{K}_{\mathrm{j}}^{\prime \prime}$ is concentration of natural water against component $\mathrm{j}$.

\section{Variational Water Management Balance of Georgia}

Based on differential assessment and modelling of economic load on water resources, alternative water management balance has been developed in Georgia.

As at present Georgia actually faces the necessity of economic revival, particularly production economy, it is of special interest water management balance of Georgia during the most active period of economic development. As it was mentioned above in the dynamics of usage of water potential of Georgia for assessment of water management elements, up to now, the most presentable was the situation in the 1980s of the last century. It was a period of maximum economic activity, in which water economy statistics were comparatively reliable, social-economic background stable and anthropogenic impact on water resources was highest possible.

As a result of the survey, it was established that at the end of the 1980 s, total water intake from water bodies was 4860 mln. $\mathrm{m}^{3}$, which made up $10 \%$ of river runoff and $28 \%$ of stable flow. At the same time, $30 \%$ water intake (1500 $\mathrm{mln} . \mathrm{m}^{3}$ ) falls to the share of transportation losses. Approximately $40 \% \quad\left(1570 \mathrm{mln} . \mathrm{m}^{3}\right)$ water usage was accounted for non-returnable losses. Annual volume of waste waters was $1720 \mathrm{mln} \cdot \mathrm{m}^{3}$, and $19800 \mathrm{mln} . \mathrm{m}^{3}$ of pure river water became unfit, i.e. $34 \%$ of total river runoff in Georgia and almost total stable flow (fig.1).

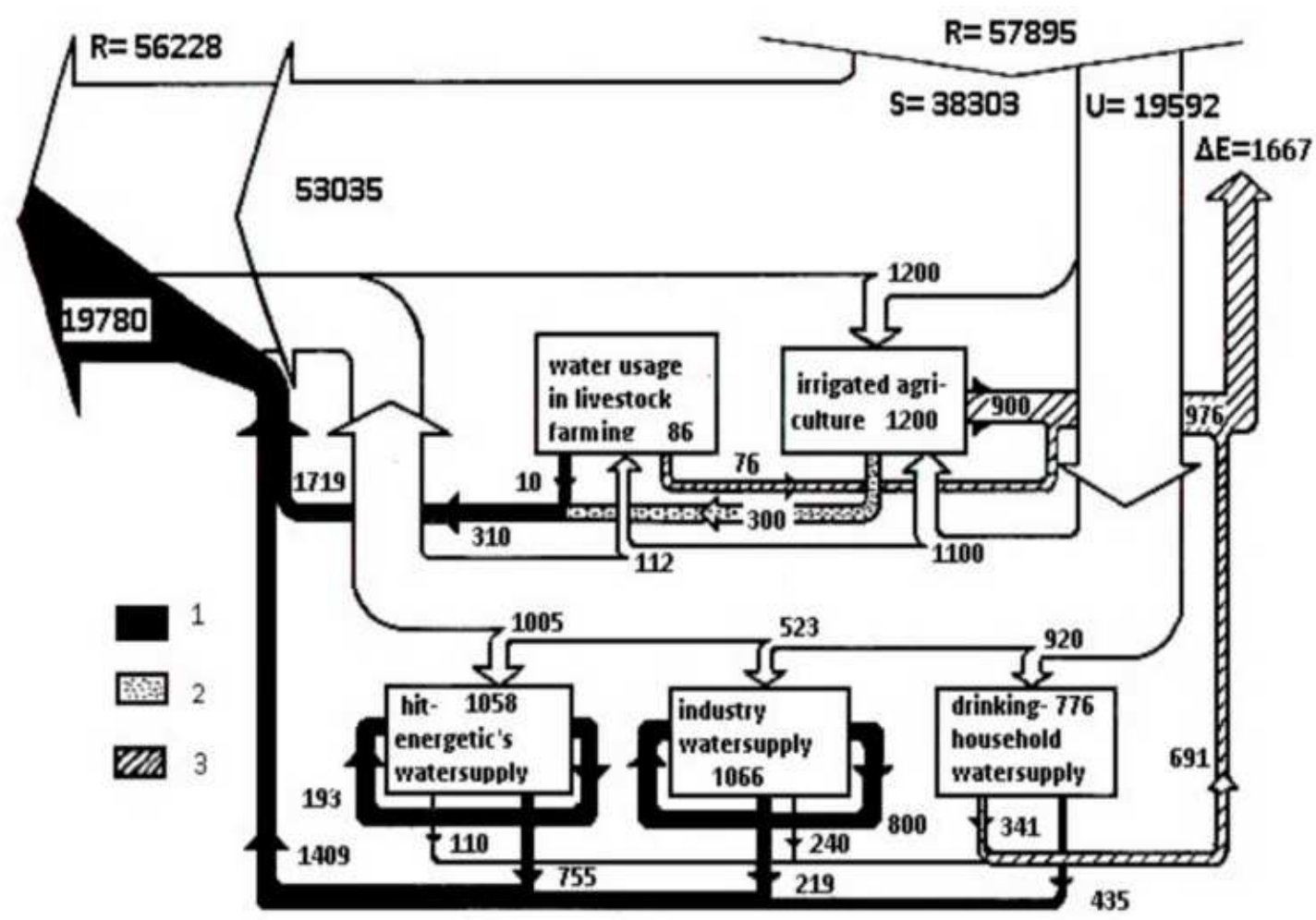

$\mathrm{R}$ - Total resources; U - Stable resources; $\mathrm{S}$ - Non-stable resources; $\mathrm{E}$ - Non-returnable loss. 1 - Polluted waters; 2 - Returned waters; 3 - Non-returned waters.

Fig. 1. Table of Water Resource Usage at the end of the 1980s (mil.m³). 


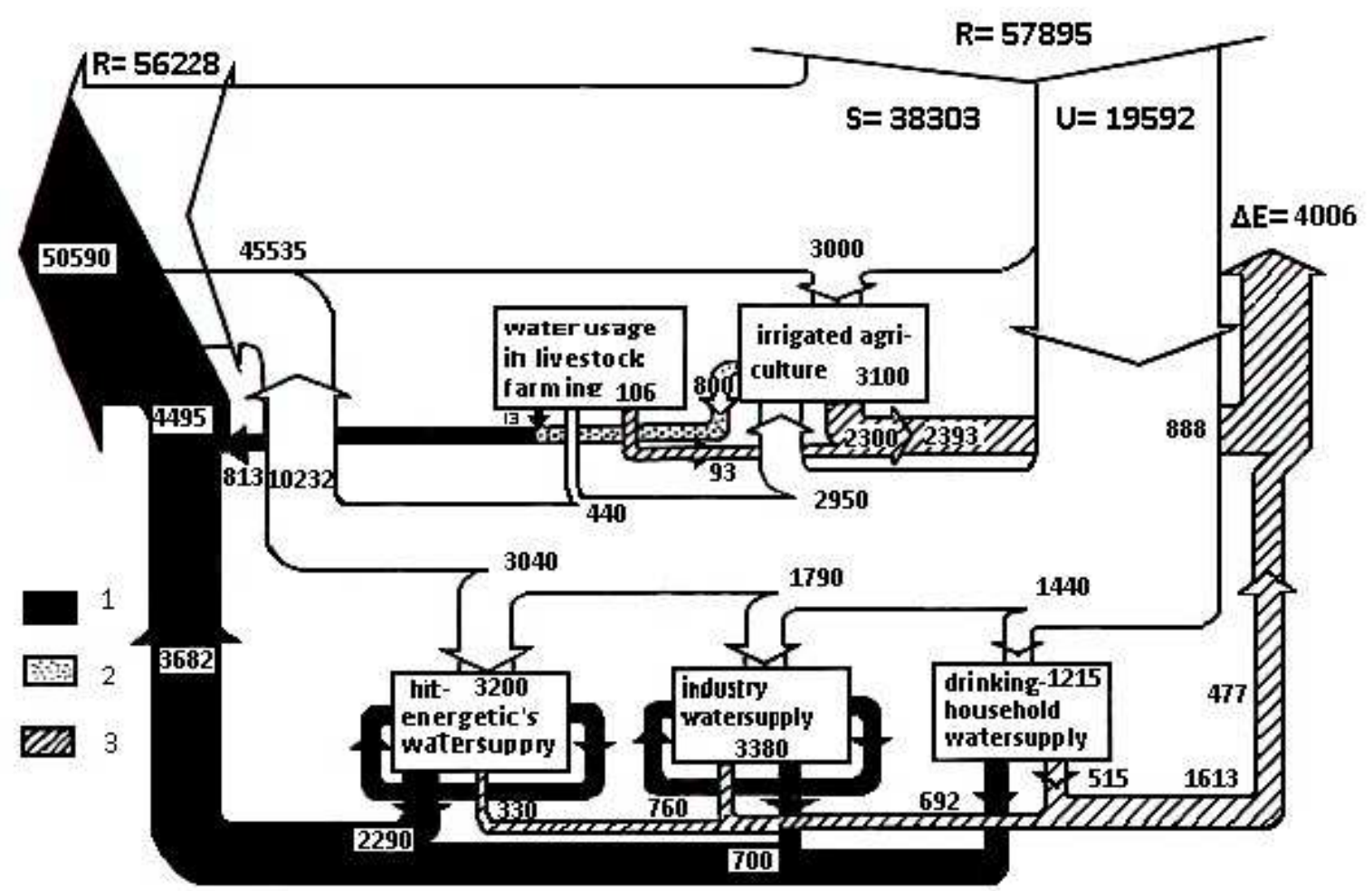

$\mathrm{R}$ - Total resources; U - Stable resources; $\mathrm{S}$ - Non-stable resources; E - Non-returnable loss.

1 - Polluted waters; 2 - Returned waters; 3 - Non-returned waters.

Fig. 2. Table of Long-term Usage of Water Resources of Georgia (Option lof the forecast) (mil.m $\mathrm{m}^{3}$ ).

The given data indicate to the critical situation of water resources of Georgia from the point of view of quality. The cause was in the low performance of cyclic/circulating water supply (19\% of water usage), as well as treated waste waters (27\% of total waste waters, from which only $4 \%$ were subject to biological treatment).

Proceeding from the principles of indicated water management, water industry faced heavy prospects. Without substantial changes of principles and standards of usage of water resources, in compliance with the state plan of development of national economy, by the first quarter of the $21 \mathrm{st}$ century, $12400 \mathrm{mln} . \mathrm{m}^{3}$ water would be necessary for water supply, which is $20 \%$ of river resources of Georgia. Non-returned loss would reach $4000 \mathrm{mln} . \mathrm{m}^{3}$, and volume of waste waters - $4500 \mathrm{mln} . \mathrm{m}^{3}$, for dilution of which, even in case of artificial treatment, it would be necessary 50000 mln. $\mathrm{m}^{3}$ water (95\% of river resources of Georgia) (Fig.2).

Thus we can conclude that in the nearest future water resources of Georgia would threaten not quantitative but mostly qualitative deficit.

As it has been repeatedly mentioned, water and waterindustry balances drawn up for entire Georgia do not adequately reflect the true picture of territorial distributionof water resources and branches of the economy. For this purpose a special survey has been carried out at the major territorial differentiation - for West and East Georgia separately.

From the point of view of water management balance tension East Georgia situation is of special interest.

As a result of the water management balance assessment of East Georgia it was established that the volume of water necessary for dilution of waste waters during the reporting period quantitatively is the same category as East Georgia river runoff resources (Fig.3).

If we take into consideration expected growth of the population, as well as further development of water use branches, according to state plans of national economy (Master plan for Development of National Economy of Georgian SSR in 1985-1988), in the case of maintaining modern principles of economic management, the total amount of used water from the beginning of 21 century would increase by 2,5 times. Correspondingly volume ofwaste waters would reach $3,2 \mathrm{~km}^{3}$. Even if the total volume of waste waters underwent high quality biological treatment, for dilution it would be necessary $22 \mathrm{~km}^{3}$ flow, which exceed river resources of East Georgia by 1,5. 


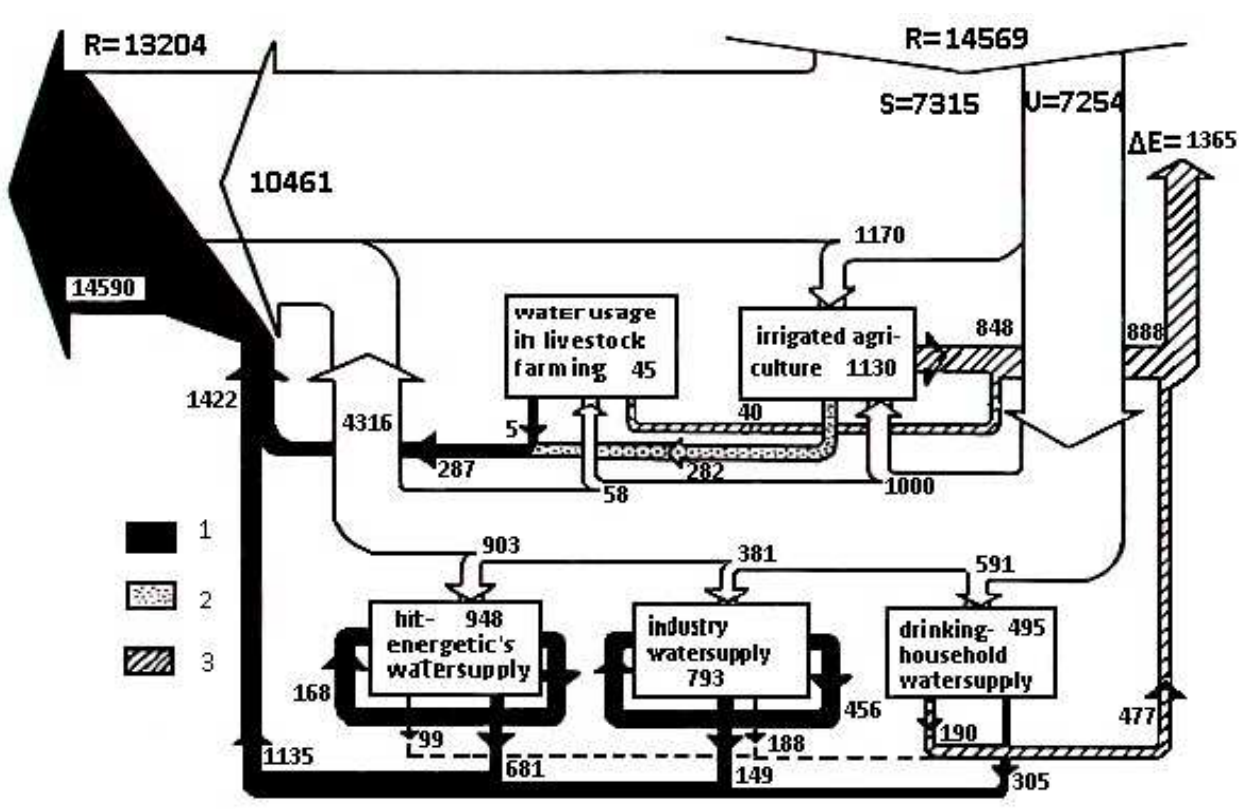

$\mathrm{R}$ - Total resources; U - Stable resources; $\mathrm{S}$ - Non-stable resources; $\mathrm{E}$ - Non-returnable loss.

1 - Polluted waters; 2 - Returned waters; 3 - Non-returned waters.

Fig. 3. Table of Use of Water Resources of East Georgia in the 1980s of the Last Century (mil.m $\left.{ }^{3}\right)$.

Thus, in the 1980s in East Georgia was facing depleting water resources quantitatively, as well as qualitatively which required to pursue an immediate strategic course of rationalization of water resources.In particular isolation ofeconomic water recycling from natural one, i.e. introduction of preventive principle in the mechanism of water resource protection - fighting causes and not results. Some practical measures connected with this principle are:Transition toclosed (cycle) water supply in industrial enterprises, maximum sewage sanitation, industrial and municipal wastewaters and their use as far as possible for technical purposes in those enterprises not requiring high quality water.At the same time, use of domestic sewage after propertreatment for irrigation of natural grasslands and technical cultures in some regions. It must also be introduced principle of universal saving of water industry at the expense of reduction of water retaining in the product, through improvement of scientifically grounded irrigation standards and methodology, in irrigation farming.

Taking into account the above mentioned principles, in case of rationalization of the water industry for expected changes in population and the same scale of economy development long-term table may be represented in the following way (Fig.4):

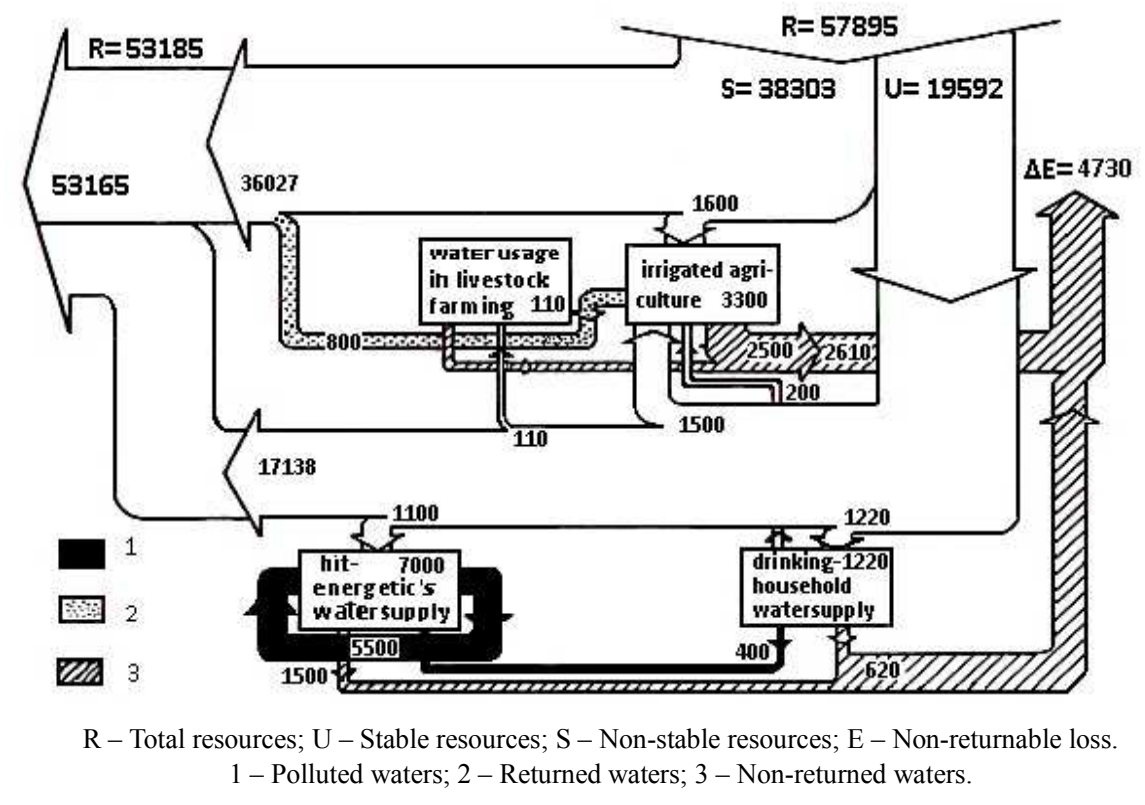

Fig. 4. Table of Long-term Use of Water Resources of Georgia (Option II of the forecast) (mil. $\mathrm{m}^{3}$ ). 
According to the given predicted option of water industry balance of Georgia non-returned loss compared to the actual one would grow by 3 times and reach $4800 \mathrm{mln} . \mathrm{m}^{3}$, but it would occur against the background of stopping waste waters in the water body. The main effect of rationalization of water economy primarily lies in protection of water resources from qualitative exhaustion which is presented as a rationalized option of the forecast. It should also be noted that this option is somehow idealized, but it can play environmental quality benchmark, which must be strictly seek.

\section{Conclusion}

The territory of Georgia is characterized by an uneven distribution of water resources in the West and East regions which causes uneven supply of the population with resources of full flow and interflow in those parts. On that basis if during the representative period selected by us for entire Georgia, waste waters polluted $1 / 3$ of the total resources of Georgia, water volume in East Georgia, necessary for wastewater treatment, has already been proportionate to theexisting resources.

Moreover, according to the scenario of long-termeconomic development of the first quarter of the currentcentury with the existing principles of water economy in the period under study for dilution of effluent waters, it would be necessary $95 \%$ of the water resources of Georgia and in East Georgia volume of water necessary for sewage sanitation would exceed the existing local resources by 1,5 times.

Taking into consideration the above mentioned in the period under study, the country has already been facing the necessity of urgent and complete reorientation of the principles of water economy. As a result of implementation of the recommended scheme of its rationalization and optimization which implied increase of quantitative impact on water recourses compared to the modern one at the expanse of increase of irretrievable water consumption, however it would be possible to avert the threat of qualitative exhaustion of water resources at the expanse of the maximum possible stopping of pollution of rivers with waste waters.

\section{References}

[1] M.Lvovich. World water resources and its future. M., 1974, 448 p. (Rus.)

[2] M.Lvovich. Water and Life. M., 1986, 254p.(Rus.)

[3] Water balance of the Caucasus and its geographical features (consistency with natural laws).Tbilisi,1991, 142p.(Rus.)

[4] N.Koronkevich, I.Zaitseva. Change in specific water consumption in the Russian Federation for the last decades. Water resources, 1999, volume I, 90-95.(Rus.)

[5] I. Bitz. Trend analyses, forecasting and long-term planning of water consumption in river basin.Scientific basis for rational utilization, conservation and management of water resources. Part I, M., 1983,78-85(Rus.)

[6] J.Alcamo, P.Döll, Th.Henrichs, F.Kaspar, B.Lehner,Th.Rösch, S.Siebert. Global estimates of water withdrawals and availability under current and future 'business-as-usual' conditions. Hydological Sciences Journal, 2003, volume 48, No. 3, pp. 339-48.

[7] F.Molle, D.Vallée. Managing competition for water and the pressure on ecosystems. WWAP (World Water Assessment Programme). United Nations World Water Development Report 3: Water in a Changing World. Paris/London, UNESCO Publishing/Earthscan, 2009,150-159.

[8] Guidelines on Strategic Planning and Management of Water Resources. ST/ESCAP/2346. New York: United Nations, 2004, 94p.

[9] Dinar, A. and Saleth, R. M. Can water institutions be cured? A water institutions health index. Water Science and Technology: Water Supply, Vol. 5, No. 6, 2005,17-40.

[10] Pres, A. 2008. Capacity building: a possible approach to improved water resources management. Water Resources Development, Vol. 24, No. 1,123-134.

[11] GWP-TAC (Global Water Partnership - Technical Advisory Committee). Integrated Water Resources Management. TAC Background Papers 4. Stockholm, GWPTAC, 2000.http://www.gwpforum.org/gwp/library/TACNO4.pdf 